\title{
STUDIES ON THE USE OF MINERAL AND BIO NITROGEN FERTILIZER WITH SOME OF GROWTH REGULATORS ON GROWTH AND YIELD OF COTTON VATIETY GIZA 80
}

\author{
SANAA G. GEBALY \\ Cotton Research Institute, Agricultural Research center, Giza. Egypt
}

(Manuscript received 6 May 2010)

\begin{abstract}
Two field experiments were carried out at Sids Agricultural Research station, Beni-suef Governumberrate in 2008 and 2009 seasons, to study the response of growth, fruiting and yield of the Egyptian cotton cultivar Giza 80 ( $G$. barbadense L.) to organic manure (sheep manures) alone or combined with mineral nitrogen fertilizer and foliar application with Kinetin and Gebirline $\mathrm{GA}_{3}$. The treatment included the control treatment, one concentration of each of kinetin $(5 \mathrm{ppm})$ and $\mathrm{GA}_{3}(100 \mathrm{ppm})$ which sprayed at the squaring stage obtained could be summarized as follows:

The combined application of $30 \mathrm{~kg} \mathrm{~N} /$ fed. as sheep manures a long with $30 \mathrm{~kg}$ mineral $\mathrm{N} /$ fed. as ammonium nitrate significantly increased plant height, Number of fruiting branches / plant, Number of open bolls / plant, boll weight in the form of seed cotton yield (feddan), seed index and chemical composition of leaf as compared with the control. (ammonium nitrate)in both seasons. Generally, the application of sheep manures at rate of $30 \mathrm{~kg} \mathrm{~N} /$ fed combined with $30 \mathrm{~kg} \mathrm{~N} /$ fed. (ammonium nitrate) and sprayed by Kinetin gave the highest cotton yield and yield components in both seasons. The studied treatments had insignificant effect on earliness $\%$ and fiber quality in both seasons.

Key words: Organic manure, Sheep, mineral N, growth regulators, kinetin, $\mathrm{GA}_{3}$, Growth, yield and yield components, Elements \%, oil, protein..
\end{abstract}

\section{INTRODUCTION}

Nitrogen is one of the most important nutrients for plants. The application of $\mathrm{N}$ fertilizer was found to be profitable up to the recommended rate $(60 \mathrm{~kg} / \mathrm{fed}$.) which increase plant height, number of fruiting branches, number of open bolls / plant, boll weight, lint \% and cotton yield (Abuldahab et al., 2000).

Losses of nitrogen fertilizers are not only impacts to the environment but also are great economic losses. Therefore, efforts should be devoted to avoid or minimize these losses.

Egyptian soil became poor in organic matter and other elements after building the High-dam. Recently, the content of total and soluble nitrogen in the soil ranged between $0.07-0.11 \%$ and $13-30 \mathrm{ppm}$. These values are low. Therefore, the Egyptian farmers provide the soil by mineral nitrogen. This performance cause on 
environmental pollution especially under the high ground water due to excessive of leaching of nitrates (Ambergerig, 1993).

Therefore, the aim of this study was to minimize mineral nitrogen fertilizer by substituting other sources of nitrogen fertilizer such as nitrogen bio-fertilizer and organic manure.

With regard to organic fertilization and on the way of safe agriculture with minimum pollution effects, the use of natural materials such as organic manures is recommended to substitute the chemical fertilizers, (Khalil et al., 2000).

The physical improvements of applying organic fertilizers to the soil were favourable soil aggregation, buffering against low $\mathrm{pH}$, slow and balanced soil mineralization, favourable water transmission potentials and resistance to erosion.

Organic manures are the alternative sources that can supply macro and micronutrients in adequate quantities, besides improving the physical properties of the soil caused a reduction to soil PH (Mehana 1998), increasing water holding capacity and improving soil structure as soil granulation buffering physical and soil aeration.

Amendment the soil with organic manures improves their physical, chemical and biological properties and hence the availability of plant nutrients.

Therefore, the objective of this study was to find out the effect of organic manures or combined with mineral nitrogen fertilizer on leaf chemical composition, growth, earliness and yield of Giza 80 cotton cultivar.

\section{MATERIALS AND METHODS}

Two field experiments were carried out at Sids experimental Station of Agricultural Research Center, Beni-Suef Governorate, Egypt during 2008 and 2009 seasons to study the effect of the combination of organic manures (sheep manures) with mineral $\mathrm{N}$ fertilizer (ammonium nitrate) besides the applications of Kinetin (a synthetic cytokinin $5 \mathrm{ppm}$ ) and Gibberlic acid $\left(\mathrm{GA}_{3} 100 \mathrm{ppm}\right)$ sprayed once at the squaring stage. Using the Egyptian cotton cultivar, Giza 80 (Gossypium barbadense L.).

Plot area was $12 \mathrm{~m}^{2}$ ( 5 ridges, $4 \mathrm{~m}$ long) and $60 \mathrm{~cm}$ a part). Distance between hills were $25 \mathrm{~cm}$ leaving two plants per hill at thinning time (after five weeks from sowing). Sowing date was an the last week of March in both seasons. A randomized complete block design with four replicates was used in both seasons, where the following eight treatments were evaluated: 
1. The recommended $\mathrm{N}$ rate ( $60 \mathrm{~kg}$ of mineral $\mathrm{N} /$ fed. as ammonium nitrate)

2. $60 \mathrm{~kg}$ of mineral $\mathrm{N} /$ fed. $+\mathrm{GA}_{3}(100 \mathrm{ppm})$.

3. $60 \mathrm{~kg}$ of mineral $\mathrm{N} /$ fed. + Kinetin ( $5 \mathrm{ppm})$.

4. $60 \mathrm{~kg} \mathrm{~N} /$ fed. In the form sheep manure $+\mathrm{GA}_{3}(100 \mathrm{ppm})$.

5. $60 \mathrm{~kg} \mathrm{~N} /$ fed. As sheep manure + Kinetin ( $5 \mathrm{ppm})$.

6. $30 \mathrm{~kg} \mathrm{~N} /$ fed. of mineral $\mathrm{N} /$ fed. $+30 \mathrm{~kg} \mathrm{~N} /$ fed. As sheep manure.

7. $30 \mathrm{~kg} \mathrm{~N} /$ fed of $\mathrm{M}$ mineral $\mathrm{N} /$ fed. $+30 \mathrm{~kg} \mathrm{~N} /$ fed. As sheep manure $+\mathrm{GA}_{3}(100$ Ppm).

8. $30 \mathrm{~kg} \mathrm{~N} /$ fed. Of $\mathrm{M}$ mineral $\mathrm{N} /$ fed $+30 \mathrm{~kg} \mathrm{~N} /$ fed. As sheep manures + Kinetin (5 Ppm).

Sheep manures were analyzed before applying the treatments according to nitrogen contet. Therefore, sheep manures which contain $60 \mathrm{~kg} \mathrm{~N} /$ fed. were 2381 and $2913 \mathrm{~kg} / \mathrm{fed}$ in the first and second seasons, respectively.

The $30 \mathrm{~kg} \mathrm{~N} /$ fed. In Sheep manures were 1190 and $1456 \mathrm{~kg} / \mathrm{fed}$ in the first and second seasons, respectively.

Soil and manure analyses were mode according to A.O.A.C. (1975), (Tables 1 and 2).

All plots were fertilized by recommended doses of the other major nutrients for the local district, nitrogen (60 kg N / fed.) and calcium superphosphate $15.5 \% \mathrm{P}_{2} \mathrm{O}_{5}$ at the rate of $150 \mathrm{~kg} /$ fed.). Potassium sulfate fertilizer was not added because the soil content was enough as shown in Table (1). The previous crop was Egyptian clover (Trifolium alexandrinum $\mathrm{L}$ ). Normal agricultural practices were followed during the two growing seasons.

The chemical analysis of some traits were carried out thorough both seasons which were,

1. Leaves content of chlorophyll, in 2008 and 2009 seasons, samples of the upper fourth leaves were collected at 15 days after the application of growth regulators to determine leaves content of chlorophyll $a, b$ and $a+b$ and carotenoids besides leaf nutrient elements contents (N, P and K) (A.O.A.C. 1975). 
Table 1. Physical and chemical properties of soil in 2008 and 2009 seasons.

\begin{tabular}{|c|c|c|}
\hline Properties & $\begin{array}{c}\text { Value } \\
2008 \\
\end{array}$ & $\begin{array}{c}\text { Value } \\
2009 \\
\end{array}$ \\
\hline Sand \% & 14.38 & 16.30 \\
\hline Silt \% & 35.15 & 36.50 \\
\hline Clay \% & 45.12 & 42.20 \\
\hline $\mathrm{CaCo3}$ & 2.20 & 1.90 \\
\hline Textural class & Clay lomm & Clay lomm \\
\hline $\mathrm{PH}$ & 7.82 & 7.30 \\
\hline E.C. $\left(d \mathrm{dsm}^{-1}\right)$ & 1.1 & 0.98 \\
\hline O.C. $\%$ & 0.60 & 0.50 \\
\hline O.M. \% & 0.92 & 0.90 \\
\hline Total soluble N (Ppm) & 40.00 & 39.08 \\
\hline \multicolumn{3}{|l|}{ Soluble cations (Ppm) } \\
\hline $\mathrm{Ca}^{++}$ & 1880 & 1540 \\
\hline $\mathrm{Mg}^{++}$ & 480 & 526 \\
\hline $\mathrm{Na}^{+}$ & 633 & 564 \\
\hline $\mathrm{K}^{+}$ & 488 & 425 \\
\hline$P$ & 17.13 & 15.50 \\
\hline \multicolumn{3}{|l|}{ Soluble anions $\left(\mathrm{meql}^{-1}\right)$} \\
\hline $\mathrm{CO}_{3}^{-}$ & 0.00 & 0.00 \\
\hline $\mathrm{HCO}_{3}{ }^{-}$ & 3.16 & 3.20 \\
\hline $\mathrm{Cl}^{-}$ & 3.25 & 2.90 \\
\hline $\mathrm{SO}_{4}^{--}$ & 3.69 & 3.45 \\
\hline
\end{tabular}


Table 2. Analysis of the organic manures (sheep manures) which used in the two seasons.

\begin{tabular}{|c|c|c|}
\hline \multirow{2}{*}{ Properties } & Value & Value \\
\hline & 2008 & 2009 \\
\hline $\mathrm{PH}$ (1:10 organic manures water) & 8.36 & 8.15 \\
\hline E.C. (1:10 organic manures water) & 7.50 & 7.95 \\
\hline O.M. \% & 35.01 & 36.05 \\
\hline Organic carbon \% & 18.90 & 18.65 \\
\hline Total N \% & 2.52 & 2.06 \\
\hline $\mathrm{C}: \mathrm{N}$ ratio & $1: 14.8$ & $1: 15.2$ \\
\hline $\mathrm{P} \%$ & 0.65 & 0.55 \\
\hline $\mathrm{K} \%$ & 20.60 & 20.75 \\
\hline Ca \% & 22.30 & 22.70 \\
\hline $\mathrm{Mg} \%$ & 2.33 & 2.38 \\
\hline $\mathrm{Na} \%$ & 12.01 & 12.50 \\
\hline Fe (Ppm) & 36 & 42 \\
\hline Mn (Ppm) & 2.9 & 3.5 \\
\hline Zn (Ppm) & 5.6 & 6.0 \\
\hline $\mathrm{Cu}(\mathrm{Ppm})$ & 6.0 & 6.42 \\
\hline
\end{tabular}

* Optimizing of micronutrient fertilizer use project, National Research Center, Unit of Mariut.

** Organic matter $(O . M)=$ organic carbon $\times 1.724$.

2. Oil and protein percentage were determined in the seeds by the method described by A.O.A.C (1975).

3. Plant growth parameters, (final plant height $(\mathrm{cm})$ and number of fruiting branches per plant).

4. Yield and yield components i.e. boll weight ( $\mathrm{gm})$, number of open bolls per plant seed cotton yield (kentars per feddan)***, Earliness \%, lint percentage and seed index.

5. Fiber properties, micronaire reading and Pressley index were determined for the representative samples

The obtained data were subjected to statistical analysis according to Gomez and Gomez (1984) and L.S.D. values at $5 \%$ level of significant were used for comparison between means.

$* * *$ kentar per feddan $=157.5 \mathrm{~kg}$ seed cotton. 


\section{RESULTS AND DISCUSSION}

\section{Effect of plant growth parameters}

\section{A. Plant height}

Data in Table (3) showed that the highest value of plant height was obtained from the combination of $30 \mathrm{~kg} \mathrm{~N} /$ fed. as mineral and $30 \mathrm{~kg} \mathrm{~N} /$ fed. as sheep manure with one spray Kinetin in both seasons. While, the lowest value of plant height was recorded in plants fertilized with recommended dose of mineral $\mathrm{N}$ fertilizer $(60 \mathrm{~kg} \mathrm{~N} /$ fed.) in both seasons, compared with those fertilized with all other treatments.

Generally, this increase may be due to the positive role of cytokinins which stimulate cell division and enlarge the cell contains. In this respect, El-shahawy and Abd El-Malik (1999) found that with higher $\mathrm{N}$ level (80 kg N / fed.) cotton plants were more efficient to get higher final plant height. Beside, the released of other macro and micro-elements from sheep manure which improved plant growth.

\section{B. Number of fruiting branches / plant}

Concerning to Number of fruiting branches / plant, the data presented in Table (3) indicated that these character increased by application of sheep manure in combination with mineral $\mathrm{N}$ fertilizer and with spraying of Kinetin in both seasons.

In this connection, it should be mention that there was a positive effect of Kinetin on Number of fruiting branches / plant as compared with Gibberellic acid (GA3). Accordingly, cytokinin is quite effective in retarding the abscission response in cotton (Cothren, 1999). Several studies indicated that number of fruiting branches / plant was significantly increased by application of Kinetin (Sawan et al., 2000 and Kassem et al., 2009).

\section{Seed cotton yield and its components}

\section{Number of open bolls / plant}

Table (3) show the effect of treatments under study on seed cotton yield / fed. and its components in the two seasons. 
Data in Table (3) show that the tested treatments of sheep manures and mineral N. fertilizer gave a significant effect on Number of open bolls / plant in the two seasons. The highest Number of open bolls / plant was observed in treatments which with $30 \mathrm{~kg} \mathrm{~N} /$ fed. of sheep manures and $30 \mathrm{~kg} \mathrm{~N} /$ fed. (ammonium nitrate) with spraying with Kinetin.

Increasing Number of open bolls / plant as a result of application of organic manure (sheep manure) is probably due to increasing the uptake of $\mathrm{N}$ and other nutrients from which released from organic manures. These results are in agreements with those obtained by El-shahawy and Abd El-Malik (1999).

On the other hand, several studies indicated that Number. of open bolls / plant was significantly increased by application of Kinetin. These results are in agreements with those obtained by Sawan et al., 2000. Also, spraying cotton plants with 50 ppm GA3 increased Number of open bolls / plant and Number. of fruiting branches / plants. These results are in agreement with those obtained by Eid and El-Aggory (1985). This might be due to the effect of both growth regulators on the increase of cell number and size which increased boll production.

\section{Boll weight}

The data in Table (3) show that the tested treatments gave significant effects on boll weight in the first season. This only increase in boll weight may be due to $\mathrm{N}$ induced increase in mineral uptake.

A reference to Table (5), it is obvious that chlorophyll was increased as a result of application of sheep manures compared with the application of $60 \mathrm{~kg}$ mineral $\mathrm{N} /$ fed (control). Therefore, increasing chlorophyll a pigment which responsible for photo-synthesis increased photosynthesis process and consequently enhanced flowering and boll retention (Kler et al., 1989).

\section{Seed cotton yield}

The data in Table (3) show that there was increase in seed cotton yield kentar / fed. in the first and second seasons by the application of Kinetin or $\mathrm{GA}_{3}$ beside the application of sheep manure. The highest value of seed cotton yield / fed. was obtained from the combination of $30 \mathrm{~kg}$ as sheep manures with $30 \mathrm{~kg}$ mineral $\mathrm{N} / \mathrm{fed}$. and spraying with Kinetin in both seasons.

Generally, there was a significant increase among all treatments in both seasons. However, treatments that received sheep manures at the rate of $30 \mathrm{~kg} \mathrm{~N} /$ fed. with $30 \mathrm{~kg}$ mineral $\mathrm{N} /$ fed and sprayed Kinetin achieved highest seed cotton yield which recorded 10.66 kentar / fed. and 9.72 kentar / fed. in the first and second season, respectively, This treatment might be as a result of increasing boll number and boll 
weight due to releasing more macro and micro elements from organic manures. Besides, the positive effect of Kinetin on growth and yield production. On the other hand, the control treatment achieved 8.59 and 7.24 kentar / fed. in the first and second season, respectively. In this respect Kassem et al (2009) found that foliar application of Kinetin significantly affected on seed cotton yield per feddan. Also Eid and El-aggory (1985) indicate that $\mathrm{GA}_{3}$ foliar application at $50 \mathrm{ppm}$ increased cotton yield.

\section{Earliness percentage}

Data in Table (4) show that the treatments under study gave insignificant effect on earliness percentage in the two seasons. In this respect, El-Shazly and ElMasri (2002) found that earliness \% was insignificantly affected by organic manures (pigeon refuse, sheep and rabbit manures).

\section{Lint percentage}

Results present in Table (4) show that lint \% was significantly affected by application of sheep manures with nitrogen fertilizer. Plants received $60 \mathrm{~kg}$ mineral N/ fed. had lower lint \% as compared with other treatments. In this respect Al-Kahal et al. (2007) found that the three sources of nitrogen (urea, fresh poultry litter and composted poultry litter) significantly increase lint yield compared with control (60 kg $\mathrm{N} /$ fed.).

\section{Seed index}

Data in Table (4) show that seed index significantly affected by tested treatments, where the highest value was obtained from the combination of sheep manures at the rate of $30 \mathrm{~kg} \mathrm{~N} /$ fed. with $30 \mathrm{~kg}$ mineral $\mathrm{N} /$ fed. and sprayed by Kinetin followed by the all treatments. The lowest value was obtained from applying sheep manures at the rate of $30 \mathrm{~kg} \mathrm{~N}$ fertilizer / fed. with $30 \mathrm{~kg}$ mineral $\mathrm{N} /$ fed. without sprayed by Kinetin or $\mathrm{GA}_{3}$. The increase in seed index may be due to the increase of photosynthetic activity which increase the accumulation of metabolites with direct impact on seed weight. These results are in agreement with those obtained by AlKahal et al. (2007). 
194 STUDIES ON THE USE OF MINERAL AND BIO NITROGEN FERTILIZER WITH SOME OF GROWTH REGULATORS ON GROWTH AND YIELD OF COTTON VATIETY GIZA 80 


\section{Fiber quality}

Data in Table (4) show that tested treatments did numbert exhibit any significant affect on micronaire reading and Pressley index in the two seasons. Similar result was obtained by Al-Kahal et al. (2007) who found that application of organic manures at different levels resulted in non significant increase in micronaire reading and Pressley index in both seasons.

\section{Effect of leaves content of chlorophyll}

Data present in Table (5) revealed that various foliar treatments of Kinetin and $\mathrm{GA}_{3}$ significantly increased leaves content of chlorophyll $\mathrm{a}$, $\mathrm{b}$ and total chlorophyll and carotenoids in comparison with the control. The highest chlorophyll content obtained from the application of organic manure (sheep manures) and $30 \mathrm{~kg}$ mineral $\mathrm{N}$ fertilizer and sprayed with Kinetin. In this respect AlKahal et al. (2007) show that chlorophyll A, $b$, total chlorophylls and carotene were significantly increased due to application of organic manure.

In this respect, Kassem et al. (2009) found that cotton plants treated with various treatments of IAA and Kinetin showed higher leaves content of chlorophyll $a, b$ and total chlorophylls. Also, addition of $\mathrm{GA}_{3}$ increases of chlorophyll (Zaghlool and Ibrahim, 2006). This increase in chlorophyll $a, b,(a+b)$ and carotene which refer to the application of sheep manures could be attributed to increasing $\mathrm{N}$ and $\mathrm{K}$ in leaves. Nitrogen is an essential nutrient in creating plant dry matter, as well as many energy rich compounds which regulate photosynthesis. There is an optimal relationship between nitrogen contents in the plant and $\mathrm{CO}_{2}$ assimilation as reported by Greef (1994), where decreases in $\mathrm{CO}_{2}$ fixation are well documented for $\mathrm{N}$-deficient plants. 
STUDIES ON THE USE OF MINERAL AND BIO NITROGEN FERTILIZER WITH SOME OF GROWTH REGULATORS ON GROWTH AND YIELD OF COTTON VATIETY GIZA 80 


\section{Leaf nutrients concentration}

Table (6) show the effect of sheep manures and mineral $\mathrm{N}$ fertilizer Applications on leaf N, P and K content during 2008 and 2009 seasons.

In general application of sheep manures with $\mathrm{N}$. fertilizer increased the concentration of $\mathrm{N}, \mathrm{P}$ and $\mathrm{K}$ in cotton leaves in generally as compared to the control treatment as shown in Table (6). The highest value of leaf $\mathrm{N}$ and $\mathrm{K}$ content were obtained from applying the combination of $30 \mathrm{Kg} \mathrm{N} /$ fed as sheep manures form with $30 \mathrm{~kg}$ mineral $\mathrm{N} /$ fed. and spraying Kinetin or $\mathrm{GA}_{3}$ in both seasons While the highest value of leaf $\mathrm{P}$ content was obtained from applying the combination of $30 \mathrm{~kg} \mathrm{~N} /$ fed. as sheep manures form with $30 \mathrm{~kg}$ mineral $\mathrm{N} /$ fed. and spraying with $\mathrm{GA}_{3}$. In general, the release of $\mathrm{GA}_{3}$ enhancing the flowering curve which lead to the increase of phosphors absorbed than nitrogen content.

Increasing $\mathrm{N}$ due to application of organic manures lead to increase protein content (Al-Kahal et al., 2007). In addition, Shafeek and El-Habbasha (2000) concluded that supplied organic manures with necessary nutrient elements and increased the microbial respiration and hence $\mathrm{CO}_{2}$ output which has reducing $\mathrm{PH}$ effect on soil. Furthermore, the slow release of nutrients from organic manures offers balanced soil solution. Stitt (1999) indicated that nitrate ( Number $_{3}{ }^{-}$) induces genes involved in different aspects of carbon metabolism, including the synthesis of organic acid used for aminumber acids synthesis. Also, increasing $\mathrm{K}$ level due to application of organic manure also increase protein. Al-Kahal et al. (2007) found that application of organic manures with or without $\mathrm{N}$ mineral fertilizer increased the concentration of $\mathrm{N}$, $\mathrm{P}$ and $\mathrm{K}$ in cotton leaves compared with those fertilized by $60 \mathrm{~kg} \mathrm{~N} /$ fed. in the form of mineral

\section{Oil and protein $\%$ in the cotton seeds}

Data in Table (6) show that the tested treatments gave a significant effect on oil and protein $\%$ in cotton seeds in the two seasons. Both characters were significantly increased by adding sheep manures combined with mineral $\mathrm{N}$ fertilizer and Kinetin or $\mathrm{GA}_{3}$. These results suggest that high $\mathrm{N}$ rate increase aminumber acid synthesis in leaves and this stimulate the accumulation of protein in the seed. Increasing $\mathrm{K}$ level due to application of organic manure also increase protein. This could be attributed to the role of $\mathrm{K}$ in biochemical pathway in plants of nitrogen.

The interaction between growth regulators (Promoters) as Kinetin and Gebirline $\left(\mathrm{GA}_{3}\right)$ on the high rate of nitrogen content led to increasing of boll setting and decrease of square and young boll shedding which reflected the increase of boll number and boll weight. 
STUDIES ON THE USE OF MINERAL AND BIO NITROGEN FERTILIZER WITH SOME OF GROWTH REGULATORS ON GROWTH AND YIELD OF COTTON VATIETY GIZA 80 


\section{REFERENCES}

1. Abuldahab , A.A. , Sohair, A.D.E. and E.S.S. Ali. 2000. Cotton growth parameters and production of Giza 75 , cotton variety as affected by sowing date and nitrogen levels. J. Agric. Sci., Mansoura Univ., 25 (12): 7367 - 7379.

2. Al-Kahal, A.A. , Alia, A.M. Namich and M.Y. Abou-Zeid. 2007. Influence of integrated system of organic manures and nitrogen fertilizer for enhancing growth, yield and activity of some major microorganisms in the rhizosphere of cotton plant. J. Agric. Sci., Mansoura Univ., 32 (11): 9407 - 9425.

3. Ambergerig, A. 1993. Dynamics of nutrients and reaction of fertilizers appalled on the environment. Proc. Of German / Egyptian / Arab Workshop in Cairo and Ismailia, Egypt, $6-17$ June PP. $41-60$.

4. A.O.A.C. 1975. Official and Methods of Analysis of Official Agricultural Chemists. $12^{\text {th }}$ ed. Washington D.C. PP. $94-117$.

5. Cothren, J.T. 1999. Physiology of cotton plant in : Cotton origin history, technumberlogy and production. W.C. Wayne (ed), John Wiley \& sons, New York, USA.

6. El-Shahawy, M.I.M, and R.R. Abd El-Malik. 1999. Response of Giza 87 cotton cultivar (Gossypium barbadense) to irrigation intervals and nitrogen fertilization levels. Egypt. J. Agric. Res., 77 (2): $841-855$.

7. El-Shazly, W.M.O. and M.F. El-Masri. 2002. A comparative study on the effect of some organic manures and mineral nitrogen fertilizer on the leaf chemical composition, growth, earliness and yield of cotton (Giza 89 cultivar). Minufiya J. Agric. Res. 27(6): 1325 - 1348.

8. Etidal,T. Eid and Eglal, A. El-Aggory. 1985. Effect of $\mathrm{GA}_{3}$ different applications on yield, yield components and mineral status of cotton plant, variety Giza 75. Annals Agric Sci., Fac. Agric., Ain-Shams Univ., Cairo, Egypt, 30 (2): 1047 - 1067.

9. Gomez, K.A. and A.A. Gomez. 1984. Statistical Procedures for agricultural research. $2^{\text {nd }}$ Ed - John Wiley \& Sons, New York, USA.

10. Greef, J.M. 1994. Productivity of maize (Zea Mays L.) in relation to morphological and Physiological characteristics under varying amounts of Nitrogen supply. J. Agron. Crop Sci., 172: 317 - 326.

11. Kassem, M.M.A. , S.A.F. Hamoda and M.A.A. Emara. 2009. Response of cotton growth and yield to foliar application with the growth regulators Indole Acetic acid (IAA) and Kinetin. J. Agric. Sci., Mansoura Univ., 34 (3): 1835 - 1843. 
12. Khalil, M.E.A. , Nadia M Badran and M.A.A. El-Emam. 2000. Effect of different organic manures on growth and nutritional status of corn. Egypt. J. Soil Sci., 40(12): $245-263$.

13. Kler, D.S. , D. Raj and G.S. Dhillon (1989). Modification of microenvironment with cotton canumberpy for reduced abscission and increased seed yield. Environ. Ecol. $7: 800-802$.

14. Mehana, T.A. 1998. Effect of N-Serve nitrogen stabilizer and chicken manure on some soil properties and mineral composition of maize plants. $7^{\text {th }}$ Conf. Agric. Dev. Res., Fac. Agric., Ain-Shams Univ., Cairo, December 14 -17, Annals Agric. Sci., Sp. Issue $1,333-348$.

15. Sawan, Z.M., A.A. Mohamed, R.A. Sakr and A.M. Tarrad. 2000. Effect of kinetin concentration and method of application on seed germination, yield components, yield and fiber properties of the Egyptian cotton (Gossypium barbadense L.). Environ. Exp. Botany, 44: $59-68$.

16. Shafeek, M.R. and K.M. El-Habbasha. 2000. Productivity of climbing bean (Phaseolus Vulgaris L.) grown under plastic house as affected by organic manures. Egypt. J. Appl. Sci., 15 (12): $192-210$.

17. Stitt, M. 1999. Nitrate regulation of metabolism and growth. Curr. Opin. Plant Biol., 2 : $178-186$.

18. Zaghlool, S.A.M. and S.I. Ibrahim. 2006. Physiological effects of gibberellic acid $\left(\mathrm{GA}_{3}\right)$ and paclobutrazol (PP333) on cotton plant. Publisher, Fac. Agric., Ain Shams University. 
دراسات على إستخدام التسميد النتروجينى المعنى والحيوى وبعض منظمات النمو

\section{على نمو ومحصول القطن لصنف جيزة 80}

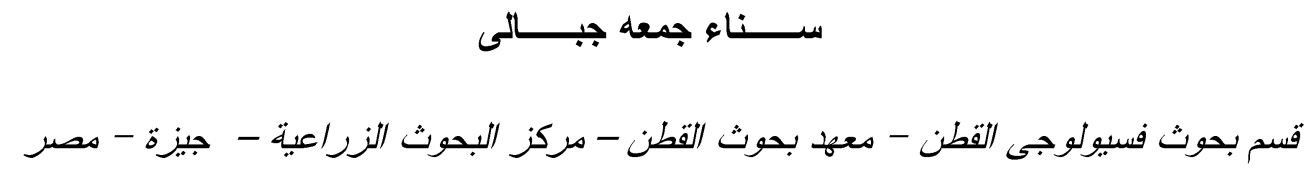

أجريت تجربتان حقليتان بمحطة البحوث الزر اعية بسدس - محافظة بنى سويف فى موسمى

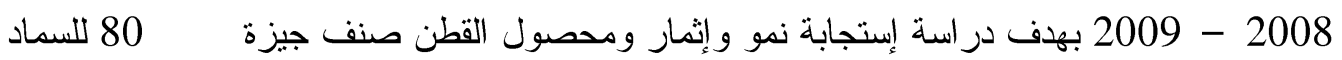

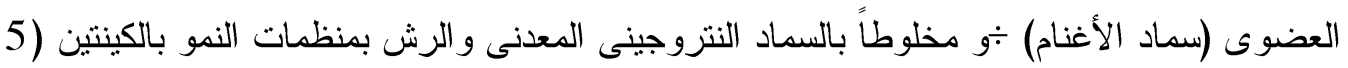

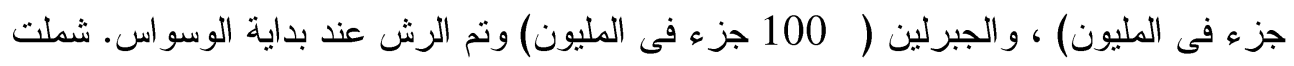

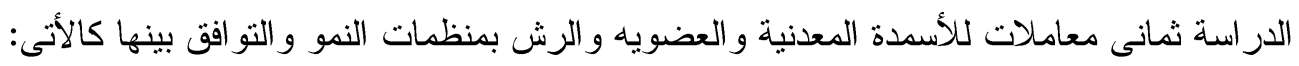
ا . 60 كجم نتزوجين للفدان سماد معدنى (معاملة المقارنة). r. 60 كجم نتروجين معدنى للفدان + جبريلين (100 جزء فئ فئ المليون). r. 60 كجم نتروجين معدنى للفدان + كينتين (5 جزء فئ المليون).

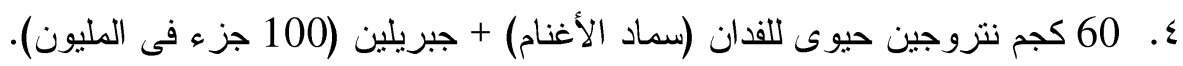
0. 60 كجم نتروجين حيوى للفدان (سماد الأغنام) + كينتين (5 جزء في في المليون). ז. 30 كجم نتروجين معدنى للفدان + 30 كجم نتروجين حيوى للفدان (سماد الأغنام). V. 30 كجم نتزوجين معدنى للفدان + 30 كجم نتزوجين حيوى للفدان (سماد الأغنام) + جبريلين

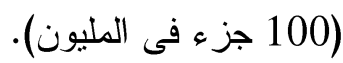

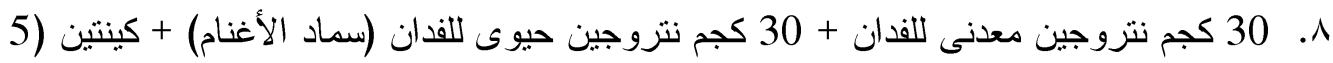
جزء فى المليون). وكان التصميم التجريبى المستخدم هو القطاعات الكاملة العشوائية فى أربعة مكررات. ويمكن تلخيص النتائج فيما يلى:

ا . أدى إستخدام 30 كجم نتزوجين للفدان فى صورة سماد الأغنام مع 30 كجم نتروجين معدنى

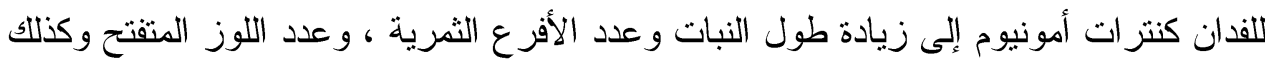

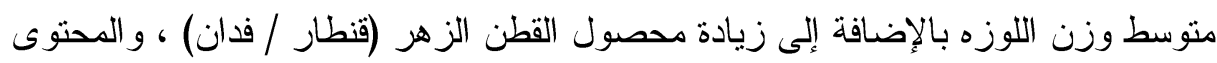

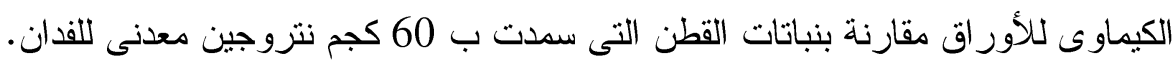

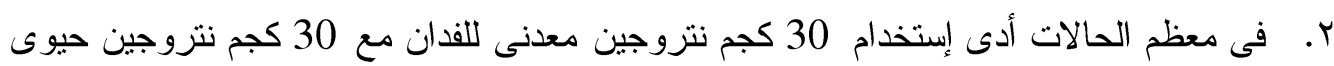

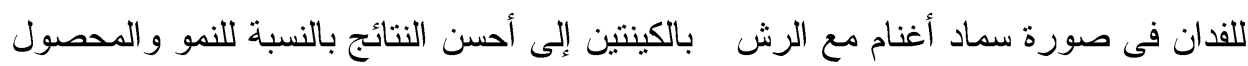
ومكوناته و المكونات الكيماوية للورقة و البذرة. r. لم تتأثز النسبة المئوية للتبكير وصفات التبلة بالمعاملات خلال موسمى الدراسة. 